\title{
APPLICATION OF A THERMOPLASTIC POLYURETHANE/POLYLACTIC ACID COMPOSITE FILAMENT FOR 3D-PRINTED PERSONALIZED ORTHOSIS
}

\author{
UPORABA VLAKEN KOMPOZITOV IZ TERMOPLASTIČNEGA \\ POLIURETANA IN POLILAKTIČNE KISLINE ZA 3D-TISKANJE \\ OPORNIC, PRILAGOJENIH OSEBNIM POTREBAM
}

\author{
Yubo Tao ${ }^{1}$, Jingjiao Shao ${ }^{1}$, Peng $\mathrm{Li}^{1 *}$, Sheldon Q. Shi ${ }^{2}$ \\ ${ }^{1}$ College of Material Science and Engineering, Northeast Forestry University, Harbin 150040, China \\ ${ }^{2}$ Department of Mechanical and Energy Engineering, University of North Texas, Denton, TX 76203, USA
}

Prejem rokopisa - received: 2018-08-15; sprejem za objavo - accepted for publication: 2018-09-20

doi:10.17222/mit.2018.180

\begin{abstract}
For designing and fabricating personalized, cost-effective and bio-degradable orthoses, a finger orthosis was chosen as an example to explore a suitable material, personalized design method, and fabrication with a fuse-deposition-modeling (FDM) open-source 3D printer. Thermoplastic polyurethane (TPU)/polylactic acid (PLA) composite filaments were explored for 3D printing. The polymer composite compositions were TPU/PLA: $0 \% / 100 \%$ (TP0), $25 \% / 75 \%$ (TP25), and 50\%/50\% (TP50) by weight, respectively. The mechanical performance, thermal properties, and structure of the TPU/PLA composite filaments were assessed by tensile tests, thermal gravimetric analysis (TGA), differential scanning calorimetry (DSC), and powder X-ray diffraction (XRD) measurements. Compared to the neat PLA, the TP25 specimens exhibited almost the same tensile strength, but its higher elongation at the break indicates that TP25 is more suitable for the material of orthoses. However, a further increase of the TPU ratio to $50 \%$ resulted in a sharp decrease of the tensile strength. The addition of TPU had little effect on the starting thermal decomposition temperature, glass-transition temperature, and melting temperature of the composites. The composite filaments can be printed through the normal 3D printing procedure. 3D scanning and open-source 3D printers can be used to complete the design and fabrication of personalized orthoses.
\end{abstract}

Keywords: 3D printing, 3D scanning; orthosis, thermoplastic polyurethane, polylactic acid

Avtorji so se ukvarjali z oblikovanjem in izdelavo cenovno ugodnih, biorazgradljivih in individualnih (osebnim potrebam prilagojenih) opornic. Na primeru opornice za prste so raziskovali ustreznost materiala, način izdelave s talilno-depozicijskim modeliranjem (FDM; angl.: Fuse-Deposition-Modeling) na 3D printerju z odprtokodno programsko opremo, ter metodo osebnega dizajna. Ugotavljali so primernost vlaken iz kompozita termoplastičnega poliuretana (TPU) in polilaktične kisline (PLA) za 3D tiskanje. Izbrane masne sestave polimernih kompozitov so bile TPU/PLA: $0 \% / 100 \%$ (TP0), 25\%/75\% (TP25), in $50 \% / 50 \%$ (TP50). Mehanske, termične in strukturne lastnosti vlaken iz TPU/PLA kompozitov so določili z nateznim (trgalnim) preizkusom, termogravimetrijo (TGA), diferencialno vrstično kalorimetrijo (DSC) in praškovno rentgensko difrakcijo (XRD). Primerjava med vzorci iz čistega PLA in vzorci iz TP25 je pokazala skoraj enako natezno trdnost pri obeh, a večji raztezek pri TP25 kaže na to, da je slednji primernejši material za izdelavo opornic. Vendar pa je nadaljnje povečanje vsebnosti TPU na $50 \%$ povzročilo močan padec natezne trdnosti vlaken. Dodatek TPU neznatno vpliva na temperaturo začetka termičnega razpada, temperature prehoda $\mathrm{v}$ steklasto stanje in temperature taljenja kompozitov. Vlakna iz izbranih kompozitov se lahko normalno izdelujejo s postopkom 3D tiskanja. Odprtokodni 3D tiskalniki omogočajo celovit dizajn in izdelavo individualnih opornic.

Ključne besede: 3D tiskanje, 3D skeniranje, opornice, termoplastični poliuretan, poliaktična kislina

\section{INTRODUCTION}

In the medical field, orthoses are used for many purposes. Depending on the patient's impairment, they might be used as braces for the rehabilitation of peripheral nerves' dysfunctions, the improvement of gait performance for people with an impaired lower-limb function, or the optimization of the support of a limb used in rheumatology, traumatology, or other articulations inflammatory processes. ${ }^{1,2}$ 3D printing (3DP), also known as additive manufacturing (AM) technology, can be defined as a technique for creating three-dimensional objects in a layer-by-layer manner. Over the past few

*Corresponding author e-mail:

lptyb@aliyun.com years, 3DP has extended to areas of aerospace, automotive, architecture, medical, education, and fashion. Nowadays, 3DP is spreading in the orthosis field. Given its low-cost and continuous materials evolution, its diffusion is expected to rapidly increase in the near future. ${ }^{3}$

Fused deposition modelling (FDM) is one of the most commonly used techniques in 3DP. The expiration of early FDM patents has led to the growth of relatively low-cost, open-source 3D printers. In essence, an FDM printer consists of an engine, gear wheels, an extrusion nozzle, and a building plate. The filament with a welldefined and consistent diameter is loaded and pushed towards the extrusion nozzle (which is set at an elevated temperature) to be melted and deposited onto a building 
plate. Dictated by the slicing software, the extrusion nozzle can be moved in different XY directions. Once each individual cross-section of the desired object is completed, the building plate can be moved down $(\mathrm{Z}$ direction) to deposit different layers. ${ }^{4}$

Polylactic acid (PLA) filaments are widely used as bio-based feedstock for FDM. Although PLA filaments are degradable and exhibit outstanding properties, its brittleness restricts their suitability for orthosis applications. Preparing PLA composites by mixing PLA with an elastomer offers a solution for ameliorating the toughness of PLA. ${ }^{5}$ Thermoplastic polyurethane (TPU) elastomers are excellent biocompatible materials for many applications in the medical field, such as blood bags and surgical gloves, catheters, synthetic veins, and wound dressings. ${ }^{6}$ Based on the chemical structure of PLA and TPU, it is possible to achieve better compatibility between both polymers. PLA is compatible with the soft polyester segments of TPU and can form hydrogen bonds with the carbamates from hard segments of TPU. ${ }^{7,8}$

3DP's most distinguishing feature is its ability to construct complex spatial objects rapidly from a digital model file. The design and production of personalized products in the pharmaceutical field, such as medicines, oral dosage forms, and medical devices, has benefitted from the advantages of 3DP.9,10 Computer-aided design (CAD) and 3D scanning technology are commonly used to generate 3D models. For personalized orthoses, 3D scanning technology offers an ideal technique for obtaining patient-specific 3D models.

In this paper, a finger orthosis was chosen as an example to explore the design and fabrication of a personalized orthosis. The TPU/PLA composite filaments were developed for FDM 3DP. The properties of the TPU/PLA composite were investigated. The feasibility of making personalized orthoses using 3D scanning and an open-source 3D printer was explored.

\section{EXPERIMENTAL PART}

\subsection{Preparation of TPU/PLA polymer composite fila- ments}

Virgin PLA (4032D) pellets were purchased from NatureWorks LLC, USA. The density is $1.24 \mathrm{~g} \mathrm{~cm}^{-3}$ and the melting temperature is about $160{ }^{\circ} \mathrm{C}$. TPU (1170A Elastonllan) pellets were obtained from the BASF Company, Germany. This is a polyether TPU with high toughness and elongation at the break, and a density of $1.08 \mathrm{~g} \mathrm{~cm}^{-3}$.

The PLA and TPU pellets were initially dehydrated $\left(103{ }^{\circ} \mathrm{C}\right)$ for 4 hours to eliminate the moisture. After drying, the TPU and PLA pellets were then blended with different ratios of TPU/PLA (0\%/100\%(TP0), $25 \% / 75 \%$ (TP25), and $50 \% / 50 \%$ (TP50) by weight and extruded using a single screw extruder (C2 model, Wellzoom LLC, Shenzhen, China) for fabricating neat PLA and TPU/PLA polymer composite filaments.
The extruder has separate temperature (maximum $320{ }^{\circ} \mathrm{C}$ ) controls for the mixture and the extrusion parts, which offers a maximum extrusion speed of $2 \mathrm{~m} \cdot \mathrm{min}^{-1}$. The extruded TPU/PLA filament was cut into smaller particles and extruded again for three times to obtain a well-mixed TPU/PLA composite filament with different TPU blend proportions. During fabrication, $1.75 \mathrm{~mm}$ filaments were used, the processing temperatures were set at $180{ }^{\circ} \mathrm{C}$ (extrusion part) and $185{ }^{\circ} \mathrm{C}$ (mixture part), with a filament yield (extrusion) speed of $1 \mathrm{~m} \cdot \mathrm{min}^{-1}$.

\subsection{Property measurements of TPU/PLA composite filaments}

The tensile properties of the specimens were measured with a universal testing machine (Changchun Kexin instruments Co. Changchun, China). The specimens were designed according to ASTM D638. Three replicates were printed from each TPU/PLA ratio composite filament for a mean value calculation. The typical stress-strain curves and elasticity modulus were obtained.

Thermal gravimetric analyses (TGA) and differential scanning calorimetry (DSC) analyses of the specimens were performed in a TA analyzer (Q 50, TA Instruments, USA) and DSC analyzer (Q 20, TA Instruments, USA). The samples were heated from $25{ }^{\circ} \mathrm{C}$ to $400{ }^{\circ} \mathrm{C}$ for the TGA and to $300{ }^{\circ} \mathrm{C}$ for the DSC with an increase rate of $10{ }^{\circ} \mathrm{C} \mathrm{min}-1$ to observe their thermal degradation behaviors. Throughout the whole procedure, the $\mathrm{N}_{2}$ flow rate was $30 \mathrm{~mL} \cdot \mathrm{min}^{-1}$.

Powder X-ray diffraction (XRD) measurements were recorded using a D/max 220 analyzer (Rigaku, Japan). The samples were scanned under conditions of a voltage of $40 \mathrm{kV}$, a current of $30 \mathrm{~mA}$, a starting angle of $5^{\circ}$, a termination angle of $40^{\circ}$, and a step width of $0.02^{\circ}$.

\section{$2.33 D$ scanning and printing}

A Sense ${ }^{\circledR}$ 3D Scanner (3D Systems, Inc. USA) was used to scan the finger to create a digital finger model of an orthosis. As shown in Figure 1a, the lens of the
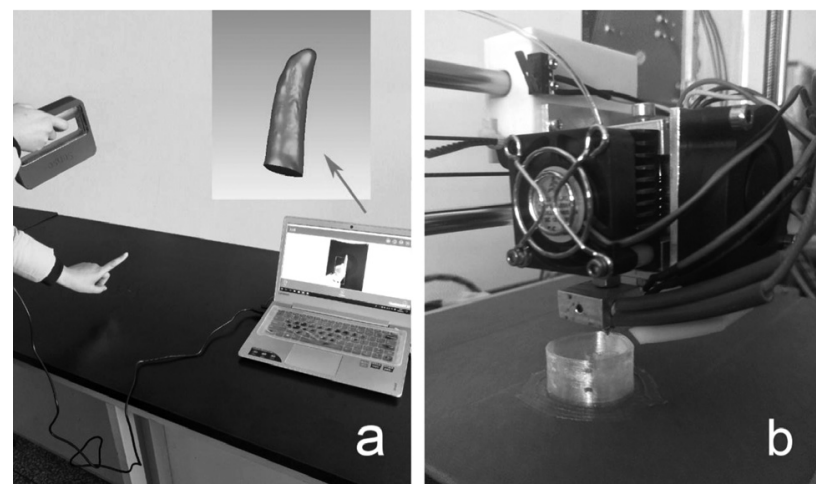

Figure 1: 3D scanning and printing: a) the finger was scanned using a 3D scanner to obtain the digital finger model, b) the finger orthosis was printed using an open-source 3D printer with FDM technology 

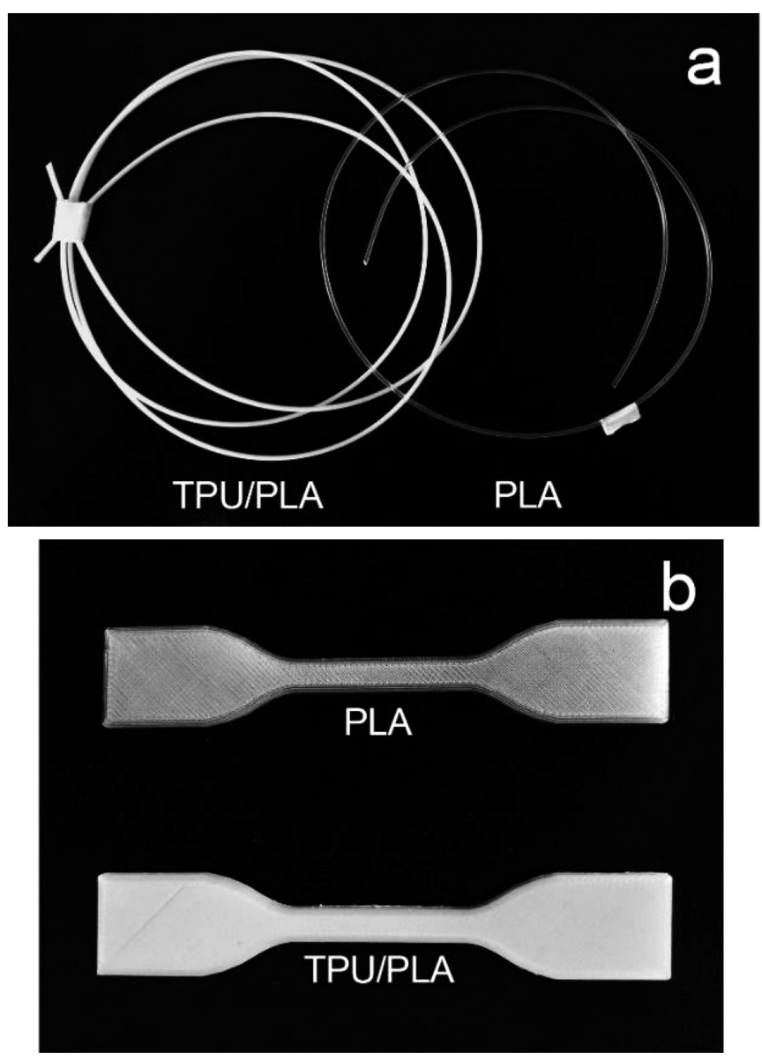

Figure 2: Filaments and test specimens: a) neat PLA and TPU/PLA composite filament, b) specimens for tensile property measurements

scanner faced and slowly rotated around the finger until the digital finger model was generated in the computer. Geomagic Studio software (developed by Geomagic Company) was used to edit the digital finger model, such as deleting misplaced polygons, etc. Then the Boolean operation of the 3DS MAX software (developed by Autodesk) was used to design the matching orthosis model. The finger orthosis model was saved in STL (Stereolithographic) format and transferred to the 3D printer.

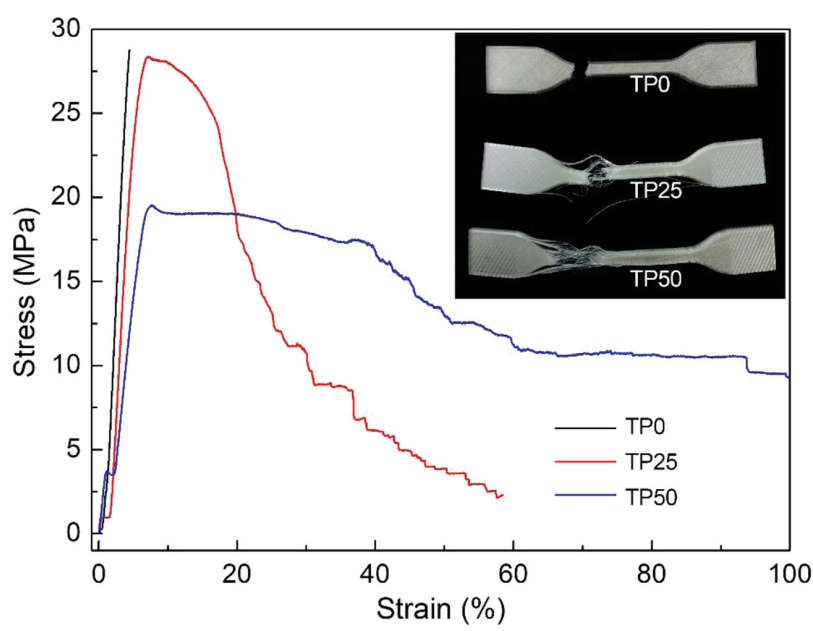

Figure 3: Typical tensile stress-strain curves of the TP0, TP25, and TP50 specimens as well as the fracture morphology of the specimens
The specimens for the tensile properties and the finger orthosis were printed with TP0, TP25, and TP50 filaments using an open-source 3D printer $(605 \mathrm{~S}$ model, Shenzhen Aurora Technology Co, Shenzhen, China). The nozzle diameter of the printer was $0.4 \mathrm{~mm}$. The CURA software (15.04 version, developed by Ultimaker) was used to set the printing parameters. The printing layer height was set to $0.3 \mathrm{~mm}$, the shell thickness to 1.2 $\mathrm{mm}$, the top and bottom thickness to $1.2 \mathrm{~mm}$, the filling density to $10 \%$, the printing speed to $30 \mathrm{~mm} \mathrm{~s}^{-1}$, the printing temperature to $200{ }^{\circ} \mathrm{C}$, the hot-bed temperature to $60{ }^{\circ} \mathrm{C}$, and the wire material flow rate to $100 \%$. The printing process of the finger orthosis is shown in Figure 1b.

\section{RESULTS AND DISCUSSION}

\subsection{Filaments and test specimens}

The neat PLA and TPU/PLA composite filaments were manufactured successfully by the extruder with a diameter of $1.75 \mathrm{~mm}$, as shown in Figure 2a. The TPU/PLA composite filaments showed a smooth surface and a uniform diameter. Compared to the neat PLA, the transparency of the TPU/PLA composite decreased. The printed specimens of neat PLA and TPU/PLA composite for the tensile property tests are shown in Figure $\mathbf{2} \mathbf{b}$. Through experimentation and observation, the TPU/PLA composite filaments were determined to be suitable for FDM printing.

\subsection{Tensile properties}

In Figure 3, the tensile stress-strain curves show that the TP0 specimen has almost no plastic deformation after the tensile yield point, and the neat PLA part undergoes brittle fracture. Nevertheless, the TP25 and TP50 specimens exhibit plastic deformation and ductile fracture after the tensile yield point. The fracture morphology of the specimens shows that TP0 suffers breakage without elongation. While the TP25 specimens can be broken after the plastic deformation, and the fibers of the TP50 specimen were stretched with no fracture. The failure characteristics of the specimens revealed that a higher TPU content results in a greater tensile toughness.

Table 1: Tensile properties of the specimens

\begin{tabular}{|c|c|c|c|}
\hline Specimens & $\begin{array}{c}\text { Tensile } \\
\text { modulus (MPa) }\end{array}$ & $\begin{array}{c}\text { Tensile strength } \\
(\mathrm{MPa})\end{array}$ & $\begin{array}{c}\text { Elongation at } \\
\text { break }(\%)\end{array}$ \\
\hline TP0 & 666.3 & 28.8 & 4.4 \\
\hline TP25 & 569.2 & 28.4 & 58.5 \\
\hline TP50 & 371.4 & 19.5 & $>100$ \\
\hline
\end{tabular}

Table 1 shows that the tensile modulus of the specimens decreases gradually with the increase of the TPU content, and while the tensile strength of the TP25 specimens undergoes insignificant changes, the elongation at break increases over tenfold. However, the tensile 
modulus and tensile strength of the TP50 specimens are greatly reduced and the elongation at break is more than $100 \%$.

The alternating hard and soft segments of its molecular chain endow the TPU with the unique properties of flexibility and elasticity. When blended with the brittle PLA, the TPU could contribute to the composite's flexibility. Furthermore, the hydrogen bond formed between the PLA and TPU molecules guarantees that at an optimized TPU addition ratio, the tensile strength of the composite will be no less than that of the neat PLA. The elongation determines the maximum deformation of a material without breakage, which is especially important from a manufacturing standpoint. Therefore, to obtain optimal performance, it is necessary to prepare PLA/TPU composites with tailored strength, modulus, and elongation. ${ }^{11}$

\subsection{DSC analysis}

As shown in Figure 4 and Table 2, the neat PLA can be characterized with a $T_{\mathrm{g}}$ at $57.9^{\circ} \mathrm{C}$, a cold crystallization temperature $\left(T_{\mathrm{c}}\right)$ around $113.1{ }^{\circ} \mathrm{C}$ and a melting temperature of $\left(T_{\mathrm{m}}\right) 153.9{ }^{\circ} \mathrm{C}$. Compared with the neat PLA, the Tg of the two TPU/PLA composites slightly decreased, which means that the TPU and PLA were partially miscible. The compatibility of polymer blends can be assessed by observing the shift in the Tg of the phases in comparison with their original values. ${ }^{12}$

The $T_{\mathrm{c}}$ of the polymer composite decreased with an increase of the TPU content, indicating that the TPU affected the cold crystallization of the PLA. These phenomena can be attributed to the added TPU, which acts as a crystallization nucleation agent by providing nucleation spots. Among the three filaments, both the cold crystallization peak and the melting peak decreased with an increase of the TPU content. ${ }^{13}$ The melting temperatures of TP0, TP25, and TP50 are about $153{ }^{\circ} \mathrm{C}$. Therefore, the printing temperature of TP25 and TP50 can equal that of the neat PLA.

Table 2: Thermal properties of neat PLA and TPU/PLA composite filaments

\begin{tabular}{|c|c|c|c|}
\hline Specimens & $T_{\mathrm{g}}\left({ }^{\circ} \mathrm{C}\right)$ & $T_{\mathrm{c}}\left({ }^{\circ} \mathrm{C}\right)$ & $T_{\mathrm{m}}\left({ }^{\circ} \mathrm{C}\right)$ \\
\hline TP0 & 57.9 & 113.1 & 153.9 \\
\hline TP25 & 57.5 & 96.2 & 153.2 \\
\hline TP50 & 57.0 & 91.1 & 152.6 \\
\hline
\end{tabular}

\subsection{Thermal gravimetric analysis}

As shown in Figure 5 and Table 3, the addition of TPU has little effect on the initial decomposition temperature (Ti) of the polymer composite. Compared to the neat PLA, when the weight loss was $10 \%$ (T10) of TP25 and TP50, the decomposition temperatures decreased less than $5{ }^{\circ} \mathrm{C}$. The fast decomposition temperature of the polymer composites shifted obviously to lower temperature ranges, and the TPU/PLA

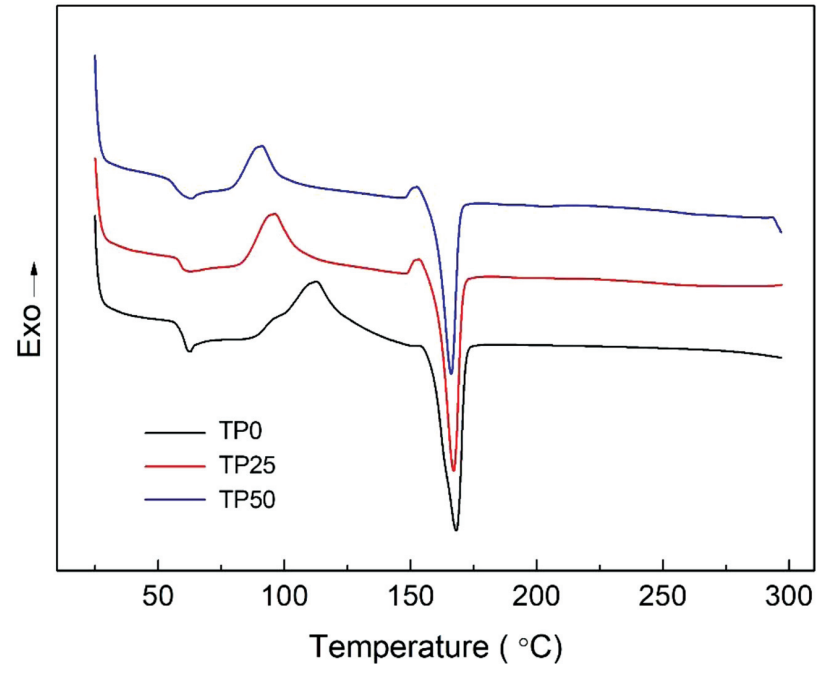

Figure 4: DSC curves of neat PLA and TPU/PLA composite filaments

composites exhibited two fast decomposition peaks. The increase of the TPU content had almost no effect on the fast decomposition temperature. Compared to the neat PLA, the heat stability of the polymer composite was reduced; the initial decomposition temperatures of the TPU/PLA composites were around $190{ }^{\circ} \mathrm{C}$. The fast decomposition temperature range was $270-280{ }^{\circ} \mathrm{C}$, which can fully meet the requirements of FDM 3D printing.

Table 3: Decomposition temperature of the neat PLA and TPU/PLA composite filaments

\begin{tabular}{|c|c|c|c|}
\hline Specimens & $T_{\mathrm{i}}\left({ }^{\circ} \mathrm{C}\right)$ & $T_{10}\left({ }^{\circ} \mathrm{C}\right)$ & $T_{\mathrm{f}}\left({ }^{\circ} \mathrm{C}\right)$ \\
\hline TP0 & 188.2 & 250.4 & 292.6 \\
\hline TP25 & 187.9 & 245.6 & $273.1,331.3$ \\
\hline TP50 & 187.7 & 247.2 & $272.8,331.1$ \\
\hline
\end{tabular}

\subsection{X-ray diffraction spectra}

In Figure 6, the XRD peak shape of the TPU/PLA composite is similar to that of the neat PLA. The neat PLA showed a broad amorphous halo at $2 \theta=16.9^{\circ}$,

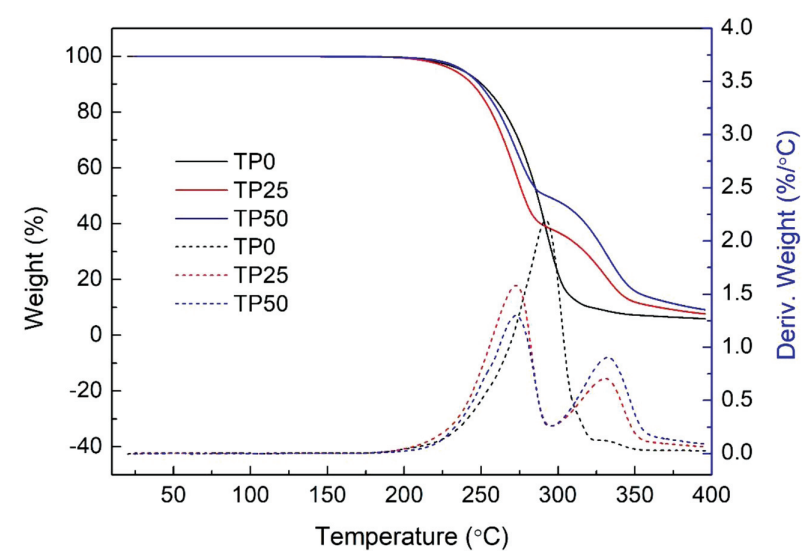

Figure 5: TGA and DTG curves of the neat PLA and TPU/PLA composite filaments 


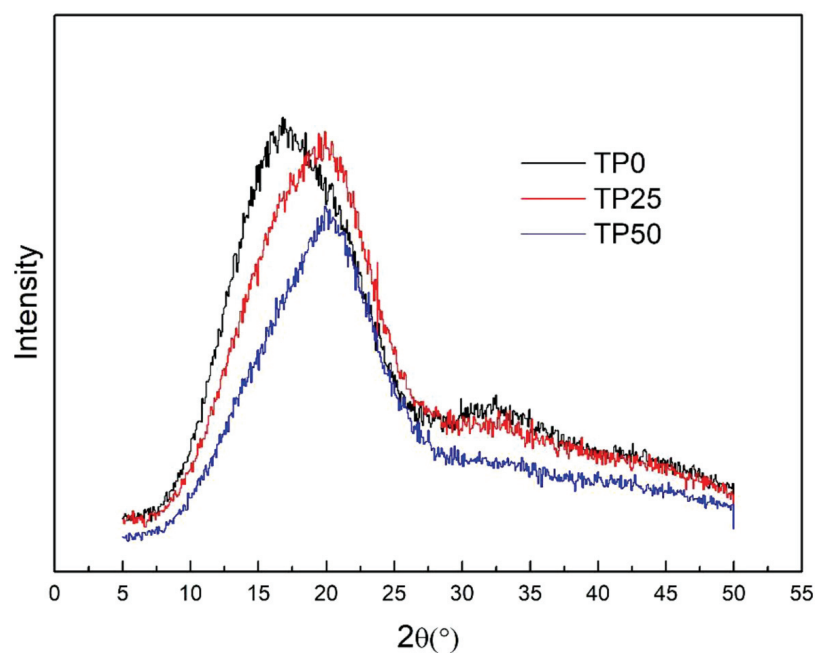

Figure 6: XRD spectra of the neat PLA and TPU/PLA composite filaments

which is the characteristic diffraction peak of the PLA crystallization. However, compared with the neat PLA, due to the contribution of the TPU, the broad halo of the diffraction peak $2 \theta=20.2^{\circ}$. The addition of TPU to PLA has a heterogeneous nucleation effect on the crystallization of PLA. After $25 \%$ TPU mixing, the peak intensity decreases slightly, and the diffraction peak of $2 \theta$ increases, indicating that the interplanar distance decreases. When $50 \%$ TPU is added, the peak width decreases, as a result of the larger grain size.

\subsection{Printed orthosis}

The TP25 has more toughness than the neat PLA, but a similar tensile strength and printing temperature with the neat PLA. Therefore, it was chosen to print the orthosis. The TP25 filament can be successively printed through FDM 3D printing, and the finger orthosis designed and printed can be a good fit, as shown in Figure 7. This indicates that the TPU/PLA composite filament is feasible for 3D printing orthoses.

\section{CONCLUSIONS}

The TPU/PLA composite filaments were prepared and the potential of the composites for an application in orthosis fabrication was evaluated. The research demonstrated that the TPU/PLA composite filament is compatible with the FDM process. Compared with the neat PLA, the addition of TPU has little effect on the starting thermal decomposition temperature, the glasstransition temperature, and the melting temperature. Without sacrificing any tensile strength, the composite with $25 \%$ TPU exhibited better toughness than the neat PLA and can be printed smoothly, just like the PLA. The results revealed that the TPU/PLA composite filament is more suitable for the design of orthoses than the neat PLA. 3D scanning and open-source 3D printers can be
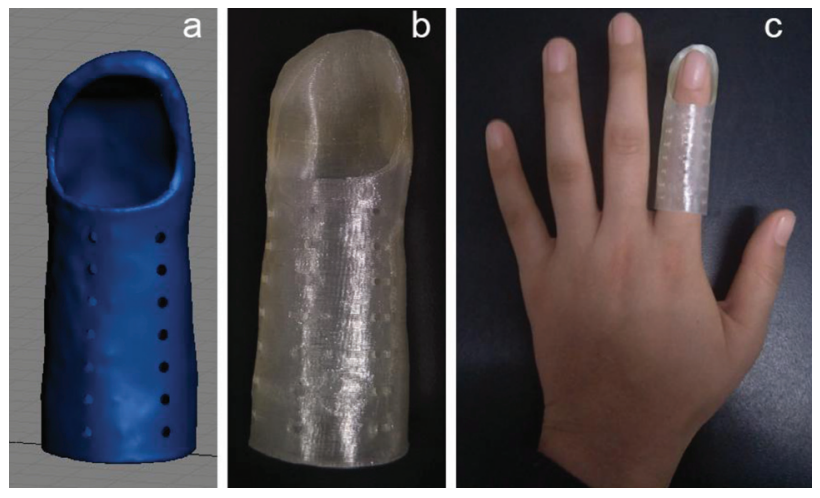

Figure 7: a) the finger orthosis model, b) printed finger orthosis and c) wearing the finger orthosis

used to complete the design and fabrication of personalized orthosis.

\section{Acknowledgment}

This project was supported by the Program for New Century Excellent Talents in University of China (NCET-13-0711). The authors would like to thank Zelong Li for his help and advice.

\section{REFERENCES}

${ }^{1}$ M. C. Faustini, R. R. Neptune, R. H. Crawford, S. J. Stanhope, Manufacture of passive dynamic ankle-foot using selective laser sintering, IEEE T. Bio-med. Eng., 55 (2008) 2, 784-790

${ }^{2}$ R. Miclaus, A. Repanovici, N. Roman, Biomaterials: Polylactic acid and $3 \mathrm{D}$ printing processes for orthosis and prosthesis, Mater. Plast., 54 (2017) 1, 98-102

${ }^{3}$ G. Baronio, S. Harran, A. Signoroni, A critical analysis of a hand orthosis reverse engineering and 3D printing process, Appl. Bionics Biomech., (2016), 8347478

${ }^{4}$ G. Verstraete, A. Samaro, W. Grymonpré, V. Vanhoorne, B.Van Snick, M. N. Boone, T. Hellemans, L. Van Hoorebeke, J. P. Remon, C. Vervaet, 3D printing of high drug loaded dosage forms using thermoplastic polyurethanes, Int. J. Pharmaceut, (2018), 318-325

${ }^{5}$ V. Jašo, M. Cvetinov, S. Rakić, Z. S. Petrović, Bio-plastics and elastomers from polylactic acid/thermoplastic polyurethane blends, J. Appl. Polym. Sci., 131 (2014), 41104

${ }^{6}$ S. H. Ajili, N. G. Ebrahimi, M. T. Khorasani, Study on thermoplastic polyurethane/polypropylene (TPU/PP) blend as a blood bag material, J. Appl. Polym. Sci. 89 (2003) 9, 2496-2501

${ }^{7}$ V. Jašo, M. V. Rodić, Z. S. Petrović, Biocompatible fibers from thermoplastic polyurethane reinforced with polylactic acid microfibers, Eur. Polym. J., 63 (2015), 20-28

${ }^{8}$ J. Han, H. Huang, Preparation and characterization of biodegradable polylactide/thermoplastic polyurethane elastomer blends, J. Appl. Polym. Sci., 120 (2011), 3217-3223

${ }^{9}$ C. L. Ventola, Medical applications for 3D printing: current and projected uses, Pharmacol. Ther., 39 (2014), 704-711

${ }^{10}$ A. Goyanes, U. Det-Amornrat, J. Wang, A. W. Basit, S. Gaisford, 3D scanning and $3 \mathrm{D}$ printing as innovative technologies for fabricating personalized topical drug delivery systems, J. Control Release, 234 (2016), 41-48

${ }^{11}$ I. S. S. Sharifah, M. D. A. Adnan, M. K. Nor Khairusshima, N. M. Shaffiar, Y. F. Buys, Effect of thermoplastic polyurethane (TPU) on the thermal and mechanical properties of polylactic acid (PLA)/ cur- 
cumin blends, IOP Conf. Series: Materials Science and Engineering, 290 (2017), 012081

${ }^{12}$ S. K. Dogan, S. Boyacioglu, M. Kodal, O. Gokce, G. Ozkoc, Thermally induced shape memory behavior, enzymatic degradation and biocompatibility of PLA/TPU blends: Effects of compatibilization, J. Mech. Behav. Biomed., 71 (2017), 349-361

${ }^{13}$ H. Mi, M. R. Salick, X. Jing, B. R. Jacques, W. C. Crone, X. Peng, L. Turng, Characterization of thermoplastic polyurethane/polylactic acid (TPU/PLA) tissue engineering scaffolds fabricated by microcellular injection molding, Mat. Sci. Eng. C, 33 (2013), 4767-4776 